\title{
TERAPI TOKEN EKONOMI UNTUK MENGUBAH PERILAKU LEKAT DI SEKOLAH
}

\author{
Nur Hasanah \\ Program Studi Kebidanan dan Keperawatan \\ STIKES Muhammadiyah Pringsewu Lampung \\ Jalan Makam KH Ghalib No. 112 Pringsewu Lampung \\ khazanah_nur@yahoo.co.id
}

\begin{abstract}
This research focused on attachment behavior at school in children's with separation anxiety disorder. Token economy is a behavior treatment to reduce attachment behavior at school. The hypothesis was economy token could change attachment behavior at school with separation anxiety disorder aged 7 years. This research design was Single Case Experimental Design with multiple-baseline design. In the research subjects was one child in elementary school with separation anxiety disorder. Data collected from monitoring sheet were analyzed with conservative-dual criteria(CDC). The form of subject's attachment figure behavior in school (1) looked into attachment figure to ensure the existence, (2) inquiring the material to his mother than his teacher at school, (3) inquiring to stay in front of the class and (4) closer to his mother than his friends when take a rest. The result shows that therapy economy token can reduce attachment behavior at school in children's with separation anxiety disorder. While the qualitative analysis shows there was parents' consistency in applying economy token program has played significant role in reducing attachment behavior at school in children's with separation anxiety disorder.
\end{abstract}

Keywords: attachment behavior at school in children's, token economy therapy, separation anxiety disorder

\begin{abstract}
Abstrak
Penelitian ini difokuskan pada perilaku lekat di sekolah pada anak yang mengalami gangguan kecemasan berpisah. Token ekonomi sebagai terapi perilaku yang digunakan dalam penelitian ini bertujuan untuk
\end{abstract}


mengurangi perilaku lekat di sekolah. Rancangan penelitian menggunakan Single Case Experimental Design dengan multiple-baseline design. Subyek penelitian berjumlah satu orang siswa sekolah dasar dengan kriteria usia 7 tahun, mengalami gangguan kecemasan berpisah dan memiliki perilaku lekat ketika di sekolah. Hasil penelitian dianalisis dengan analisis kuantitatif yaitu metode conservative-dual criteria(CDC). Bentukbentuk perilaku lekat di sekolah pada subyek penelitian berupa (1) perilaku memastikan keberadaan figure lekatnya dan menangis ketika tidak berada di tempat, (2) perilaku bertanya materi/tugas kepada ibunya dibanding guru ketika di sekolah, (3) perilaku meminta di tunggu di depan kelas oleh ibunya dan (4) perilaku mendekat ibunya ketika istirahat disbanding temannya. Hasil penelitian menunjukan bahwa terapi token ekonomi dapat mengurangi perilaku lekat di sekolah pada anak yang mengalami gangguan kecemasan berpisah. Sedangkan hasil analisis kualitatif menunjukan bahwa konsistensi orangtua dalam pelaksanaan terapi token ekonomi memiliki peran yang signifikan dalam mengurangi perilaku lekat di sekolah pada anak yang mengalami gangguan kecemasan berpisah.

Kata kunci: gangguan kecemasan berpisah, perilaku lekat di sekolah pada anak, terapi token ekonomi.

\section{Pendahuluan}

Dalam kehidupan awal seorang anak, orangtua mempunyai arti penting bagi kehidupannya. Hubungan antara anak dan figur orangtua sangat menentukan perkembangan selanjutnya. Menurut Bowlby (Dagun, 2002) kelekatan figur ibu dan anak merupakan sesuatu yang alami sifatnya karena kelekatan merupakan suatu ikatan emosional yang kuat yang dikembangkan anak melalui interaksinya dengan orang yang mempunyai arti khusus dalam kehidupannya, biasanya ibu.

Salah satu permasalahan muncul dihadapi orangtua dan anak saat anak pertama kali anak harus berpisah dalam waktu yang cukup lama dengan orangtua yang menjadi figur kelekatan, yang biasanya dialami saat anak menjalani pendidikan di taman kanakkanak, yang ditandai adanya rasa cemas anak untuk berpisah dari orangtua atau pengasuhnya. Hal ini wajar karena kedekatan anak-orangtua terjalin sejak kecil saat anak terpenuhi kebutuhan dasarnya. Namun, perilaku anak menjadi tidak wajar ketika dalam memelihara kedekatannya dengan orangtua pada anak muncul rasa tidak aman 
yang disebabkan oleh perilaku ibu yang terlalu melindungi atau overprotektifatau suka mengatur segala hal, sehingga ibu tidak dapat mempercayakan pengasuhan kepada orang lain (Kompas, 2009). Legerstee dan Ferdinand (Mofrad dkk, 2009) juga menyatakan bahwa ada hubungan positif antara sikap overprotektif orangtua dan kecemasan pada anak yang mengalami gangguan kecemasan berpisah.

Menurut Schlosberg (Parenting, 2010), banyak terjadinya stress pada anak usia sekolah ketika memasuki sekolah baru dan senantiasa meminta ibunya untuk menunggu ketika sekolah sampai selesai, bahkan terjadi aksi guling-mengguling dan menangis ketika harus berpisah dengan ibunya. Fenomena yang terjadi di sebuah sekolah dasar di Yogyakarta bahwa beberapa orangtua khususnya ibu banyak menghabiskan waktunya untuk menunggu putranya sekolah. Hasil wawancara dari salah satu guru di sekolah menunjukkan bahwa fenomena menunggu anak ketika sekolah terjadi kemungkinan karena kurang adanya aktivitas yang dimiliki seorang ibu kecuali mengurus anak dan keluarganya sehingga ibu senantiasa mengikuti sekolah ketika anak sekolah.

Pihak sekolah banyak mengeluh akan kondisi yang terjadi dalam proses belajar mengajarnya, perilaku menunggu di sekolah membuat anak kurang mandiri untuk mengerjakan tugas akademik atau menjalankan fungsi sosialnya. Kebingungan sempat melanda para guru-guru di sekolah karena berbagai cara sudah dilakukannya dengan memberi pengertian kepada orangtua untuk meninggalkan anaknya ketika sekolah dengan menawarkan memberi hadiah ketika mau ditinggal sekolah atau sebaliknya memberikan pengertian kepada anak untuk tidak ditunggu ketika sekolah, akan tetapi justru terjadi kemogokan sekolah pada anak dan anak merasa takut ketika ibunya meninggalkannya.

Gangguan kecemasan berpisah (Separation Anxiety Disorder) merupakan bentuk kecemasan yang dialami anak-anak ketika mereka akan meninggalkan rumah dan keluarga mereka untuk bergabung dengan teman-temannya di sekolah yang ia anggap sebagai orang asing. Kecemasan ini dapat mempengaruhi fungsi-fungsi kehidupan anak sehingga anak tidak bisa mandiri dan orangtua harus terlibat lebih dalam aktivitas anak (Le fanu, 2006).

Keterlibatan orangtua yang berlebih pada aktivitas aktivitas anak merupakan faktor resiko berkembangnya perilaku lekat anak-orangtua sebagai hasil kecemasan yang meningkat. Begitu pula pada anak yang mengalami kecemasan berpisah senantiasa memiliki kebutuhan untuk bersama dengan figur lekatnya untuk menerima cinta dan mendapatkan dukungan atas aktivitas yang dilakukannya seperti terlibat pada aktivitas sosial untuk mendapatkan penghargaan dari temannya (Bowbly 
dalam Wood 2007), sehingga ketidakhadiran figur lekat disampingnya membuat anak menjadi semakin defensif, anak mengeluhkan bahwa tak ada orang mencintainya atau peduli terhadapnya dan berfikir untuk bunuh diri ketika dipisahkan dengan figur yang dilekatinya. Anak menunjukkan kemarahan atau kadang memukul seseorang yang memaksa untuk berpisah dengan figur lekatnya (APA, 2000).

Menurut DSM IV (APA, 2000) Gangguan Kecemasan Berpisah (SAD) adalah kecemasan berlebihan tentang pemisahan dari rumah atau figur lekatnya, biasanya ibu yang mengakibatkan distress. Saat terjadi pemisahan anak merasa khawatir tentang dirinya tanpa adanya figur lekat disisinya sehingga sering terjadi penolakan ketika pergi sekolah dan memilih tinggal di rumah bersama figur lekatnya. Adapun faktor-faktor yang mempengaruhi terjadinya gangguan kecemasan berpisah adalah terjadinya transisi dalam lingkungan baru yaitu sekolah, adanya hubungan kelekatan yang tidak aman, dan pengalaman keluarga yang negatif, yang menunjukkan kontribusi besar untuk kecemasan (Chorpita, 2001). Dalam penelitiannya, Kearney (2001) menyatakan anak yang menolak sekolah yang mengalami kecemasan berpisah ditemukan adanya keluhan somatik yang memburuk (75\%), khawatir atas perpisahan (71\%), perilaku menolak sekolah $(69 \%)$, penolakan untuk tidur sendiri $(63 \%)$ perilaku lekat pada figur yang dilekati (56\%), khawatir akan bahaya pada orang yang dilekati (44\%), kekhawatiran tentang kejahatan (31\%) dan mimpi buruk tentang perpisahan (13\%). Anak dengan gangguan kecemasan berpisah perlu mendapat perhatian khusus, mengingat gangguan ini semakin banyak ditemukan dan mengakibatkan berbagai problem.

Salah satu permasalahan yang terjadi pada anak yang mengalami gangguan kecemasan berpisah adalah terjadinya perilaku lekat pada figur lekatnya yaitu ibu. Menurut Mannasis (dalam Mofrod dkk, 2010), kecemasan dan kegelisahan yang dialami anak untuk ditinggalkan ibunya akan menimbulkan strategi coping yang berpusat pada kewaspadaan kronis yang dapat terus berlangsung sepanjang kehidupan anak yang berakibat pada penarikan diri, tidak memiliki keberanian mengeksplorasi dan cenderung lekat pada figur lekatnya dalam lingkungan sosialnya seperti sekolah. Gewirtz \& Pelaez-Nogueras (dalam Flood \& Wilder, 2004) juga menyebutkan bahwa gangguan kecemasan berpisah termasuk gangguan kelekatan pada anak.

Mofrad dkk (2010) mengatakan dalam penelitiannya bahwa adanya hubungan antara kelekatan ambivalent dengan gangguan kecemasan berpisah. Diperkuat oleh 
Bowen (dalam Nichols dan Schwartz, 1998) bahwa kecemasan berpisah merupakan bentuk kelekatan patologis yaitu kelekatan cemas, sedangkan kelekatan cemas membuat anak tidak mau berpisah dengan orangtuanya. Selain itu, Obegi dan Berant (2009) juga mengemukakan bahwa pada diri anak yang mengalami kelekatan cemas muncul adanya ketakutan ketika ditinggal figur lekatnya dan menjadi ingin sangat dekat dengan figur lekatnya.

Perilaku lekat pada anak yang mengalami Separation Anxiety Disorder (SAD) ditandai oleh adanya perasaan khawatir adanya perpisahan dengan orangtua atau sosok yang dilekati. Perilaku lekat merupakan suatu bentuk perilaku yang dihasilkan dari usaha seseorang untuk mempertahankan kedekatannya dengan seseorang yang dianggap mampu memberikan perlindungan dari ancaman lingkungan terutama saat seseorang merasa takut, sakit dan terancam (Bowlby dalam Durkin 1995). Selain itu, perilaku lekat merupakan tingkah laku yang khusus pada manusia, yaitu kecenderungan dan keinginan seseorang untuk mencari kedekatan dengan figur lekat untuk mencari kepuasan dalam hubungan dengan figur lekat tersebut (Monk dkk, 2002).

Berdasarkan permasalahan tersebut di atas, maka perlu adanya intervensi yang dapat memberikan manfaat praktis bagi orangtua untuk menangani perilaku lekat di sekolah pada anak yang mengalami gangguan kecemasan berpisah. Menurut Kearney (2001) terapi perilaku termasuk intervensi yang paling disetujui oleh praktisi dalam penerapan perilaku lekat di sekolah pada anak yang mengalami kecemasan berpisah. Terapi perilaku merupakan perilaku yang menekankan pada pengamatan perilaku nyata, memperbaiki perilaku yang tidak adaptif dan meningkatkan perilaku adaptif (Corey, 1997).

Banyak pendekatan yang dapat digunakan untuk menangani anak yang mengalami gangguan kecemasan berpisah (SAD) antara lain Doobay (2008) menggunakan pendekatan kognitif perilaku untuk menangani perilaku menolak sekolah pada anak yang mengalami gangguan kecemasan berpisah. Kearney dkk (2003) menggunakan analisis keluarga untuk menangani kecemasan berpisah pada anak Gosschal (2004) dan Flood \& Wilder (2004) menggunakan terapi perilaku dalam menangani gangguan kecemasan berpisah (SAD) dan dinilai lebih efektif dalam penerapannya.

Token ekonomi telah banyak diteliti dan terbukti efektif diberbagai latar belakang, baik sekolah, mulai dari taman kanak-kanak sampai sekolah menenengah, klinik psikiatri serta lembaga rehibilitasi anak-anak dengan permasalahan perilaku (Field, Nash, Handwearl \& Friman, 2004; Reitman, Murphy, Hupp \& O’Collaghan, 
2004). Token ekonomi merupakan intervensi yang paling banyak diteliti dan terbukti valid dalam setting sekolah (McLaughlin \& Williams, 1998).Token ekonomi yang telah terbukti efektif untuk meningkatkan ketrampilan akademik di sekolah umum diasumsikan mampu untuk mengurangi perilaku lekat di sekolah pada anak yang mengalami gangguan kecemasan berpisah.

Penelitian terdahulu yang membahas token ekonomi sering dilakukan. Berbagai penelitian yang berkaitan dengan token ekonomi telah banyak dilakukan oleh para ahli psikologi, khususnya psikologi pendidikan dan klinis namun penelitian tersebut dilakukan untuk mengetahui penerapan token ekonomi dengan aspek lain. Penelitian Higim, William dan McLauglin (2001), tentang penerapan token ekonomi pada anak sekolah yang mengalami hambatan belajar. Hasil penelitian menunjukan bahwa penerapan token efektif mengatasi kesulitan pada anak yang mengalami hambatan belajar. Penelitian Zlomke (2003) tentang token ekonomi dan monitoring diri efektif untuk mengurangi perilaku distruktif dalam kelas dan penelitian Ningsih (2005) tentang token ekonomi untuk menurunkan perilaku agresif pada anak usia sekolah.

Lain halnya penelitian Suprihatin (2009) tentang penerapan token ekonomi pada anak yang mengalami gangguan pemusatan perhatian dan hiperaktif. Hasil penelitian menunjukan bahwa adanya peningkatan perilaku memperhatikan pelajaran pada anak yang mengalami ganguan pemusatan perhatian perhatian dan hiperaktifitas. Sampai sejauh ini peneliti belum menemukan penelitian yang menggunakan token ekonomi sebagai perlakuan untuk anak yang mengalami kecemasan berpisah ketika di sekolah.

Oleh karena itu peneliti ingin menggunakan metode token ekonomi sebagai perlakuan yang diuji. Bertolak dari prinsip dasar terapi perilaku yang menekankan pada pengamatan perilaku nyata, memperbaiki perilaku yang tidak adaptif dan meningkatkan perilaku adaptif, token ekonomi merupakan salah satu tehnik membentuk perilaku dan meningkatkan perilaku yang adaptif dengan cara memberikan pengukuh yang sifatnya sementara berupa kepingan/kartu/meterai segera setelah perilaku yang diinginkan terjadi, setelah terkumpul dalam jumlah tertentu akan ditukarkan/diuangkan dengan pengukuh yang diharapkan (pengukuh idaman). Oleh karena itu perlakuan dengan token ekonomi akan bermanfaat untuk mengatasi perilaku lekat di sekolah pada anak yang mengalami gangguan kecemasan berpisah (SAD).

Hipotesis yang diajukan dalam penelitian ini adalah adanya pengaruh terapi token ekonomi untuk mengurangi perilaku lekat di sekolah pada anak yang mengalami gangguan kecemasan berpisah. 


\section{Metode Penelitian}

Subjek dalam penelitian ini adalah satu orang anak yang mengalami gangguan kecemasan berpisah sesuai dengan kriteria DSM IV dan diungkap menggunakan wawancara terhadap figur lekatnya. Karakteristik subjek penelitian yaitu (1) anak mengalami perilaku lekat di sekolah dalam kategori tinggi, (2) memiliki usia minimal 5 tahun dan (3) sedang menjalani pendidikan formal. Subjek dikenai program token ekonomi untuk mengurangi perilaku lekat ketika di sekolah.

Penelitian ini dilakukan dengan menggunakan jenis penelitian yang tergolong Single Case Experimental Design, dengan jumlah subjek dibawah 10 orang (Barlow $\&$ Hersen, 1984). Penelitian ini bertujuan untuk menguji pengaruh pemberian token ekonomi terhadap perilaku lekat di sekolah pada anak yang mengalami gangguan kecemasan berpisah. Rancanagan penelitian Single Case Experimental Design menggunakan model rancangan multiple-baseline designs. Model rancangan multiple-baseline design dipilih dengan tujuan untuk mengetahui apakah suatu treatment dapat merubah beberapa perlaku spesifik dalam satu waktu dari seorang individu.

Penerapan token ekonomi diberikan hanya satu kali perlakuan, yang terdiri dari empat kali penukaran hadiah pada setiap kali perilaku target terbentuk. Perilaku target pertama pada hari ke 14 sampai hari ke 16 yaitu ketika subjek mau ditunggu ibunya di depan pagar dan tidak terlihat anak maka mendapatkan hadiah yang diinginkan. Perilaku target kedua pada hari ke 18 sampai 20 yaitu ketika anak mau ditunggu oleh ibunya di luar pagar sekolah maka anak akan mendapatkan hadiah yang diinginkan. Perilaku target ketiga pada hari ke 21-23 yaitu ketika ibu hanya datang ketika istirahat saja dan perilaku target keempat pada hari 24-26 yaitu ketika anak hanya cukup diantar dan dijemput ibunya saat sekolah. Poin atau stiker bergambar yang diperoleh subjek dapat ditukar dalam waktu tiga hari sekali setiap subjek telah mencapai keberhasilan perilaku yang dijadikan target. Hadiah yang akan didapatkan sesuai dengan jumlah stiker yang didapatkan dan jumlah stiker dapat dilihat pada tabel harga stiker yang ada pada peraturan program. Selama token ekonomi diberikan, orangtua, guru dan observer selaku pelaksana program terlibat dalam pelaksanaannya.

Data penelitian dianalisis menggunakan metode conservative dual-criterion (CDC) dari Swoboda et al (2010) yaitu berdasarkan analisis visual melalui grafik yang disajikan. Kelebihan dari metode CDC ini adalah mengatasi masalah rendahnya reliabilitas interrater dan menentukan apakah sebuah perubahan terjadi secara 
sistematis (bukan random). Penentuan dari efektifnya sebuah intervensi dilihat dari apakah skor yang didapat dari perilaku target di atas atau di bawah garis level (level line) dan garis trend (trend line). Sebagai contoh jika sebuah intervensi untuk menurunkan sebuah perilaku sebanyak 9 kali sesi intervensi, maka minimal 8 sesi intervensi tersebut skornya harus di bawah garis level dan garis trend. Tabel $1 \mathrm{di}$ bawah ini menyajikan kriteria skor untuk menentukan apakah sebuah intervensi membawa perubahan yang sistematis.

\section{Tabel 1}

Kriteria skor penentuan terjadinya perubahan sistematis

\begin{tabular}{lc}
\hline Jumlah skor sesi intervensi & $\begin{array}{l}\text { Jumlah skor yang dibutuhkan terjadinya } \\
\text { perubahan memprediksikan arah sistematis }\end{array}$ \\
\hline 5 & 5 \\
$6-7$ & 6 \\
8 & 7 \\
$9-10$ & 8 \\
$11-12$ & 9 \\
\hline
\end{tabular}

\section{Hasil dan Pembahasan}

Berdasarkan hasil analisis secara deskriptif, terdapat penurunan dari fase baseline ke fase treatment. Pada grafik diatas menggambarkan dinamika perubahan pada empat perlakuan perilaku lekat dalam sekolah pada subjek penelitian. Perilaku lekat I menunjukkan perilaku memastikan keberadaan ibunya dan menangis jika ibu tidak berada ditempatnya. Perilaku lekat II menunjukkan perilaku menanyakan materi/ tugas kepada figur lekatnya dibanding gurunya. Perilaku lekat III menunjukkan perilaku mendekat figur lekatnya ketika istirahat dibanding temannya dan Perilaku lekat IV menunjukkan perilaku minta ditunggu oleh figur lekatnya didepan kelas.

Secara visual terlihat bahwa seluruh perilaku lekat mengalami perubahan pada saat fase A, fase B dan follow-up, artinya dapat dikatakan bahwa program token ekonomi memberikan pengaruh langsung terhadap penurunan perilaku lekat. Pada perilaku lekat I menunjukan penurunan perilaku secara stabil. Begitu pula perilaku lekat II terlihat adanya penurunan perilaku. Lain halnya, perilaku lekat III, pada saat perlakuan (fase B) terjadi penurunan yang stabil. 
Berbeda dengan perilaku lekat IV, subjek terlihat mampu mengkondisikan dirinya untuk berpisah secara bertahap dengan orangtunya akan tetapi saat dilakukan pengukuran kembali tejadi pelonjakan perilaku meminta untuk ditunggui oleh figur lekatnya kembali. Artinya, terjadi penurunan perilaku lekat IV saat diberi fase perlakuan (B).

Perilaku lekat I: Perilaku memastikan keberadaan ibunya dan menangis jika ibu tidak berada ditempat. Gambar perilaku memastikan keberadaan ibunya dan menangis jika ibu tidak berada ditempat menunjukkan bahwa pada fase baseline terlihat perilakunya cenderung meningkat dan stabil, namun setelah diberikan perlakuan, perilaku menengok untuk memastikan keberadaan ibunya saat di sekolah cenderung menurun. Gambar 1 di bawah ini menyajikan perubahan perilaku lekat anak.

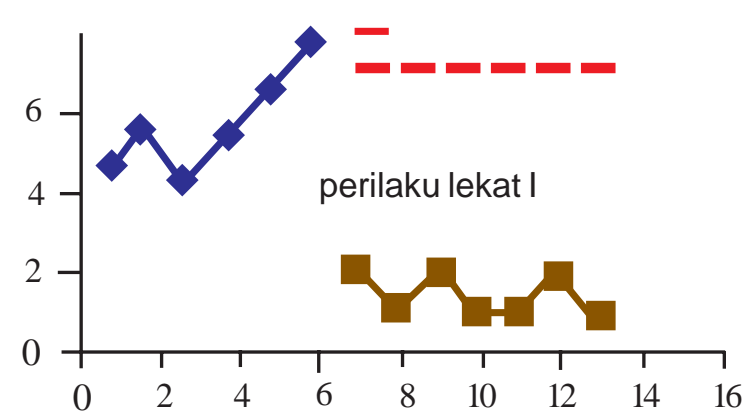

Gambar 1

perubahan perilaku lekat I anak

Pada perilaku memastikan keberadaan ibunya dan menangis jika ibu tidak berada ditempat menunjukkan adanya kemunculan perilaku dalam 3 hari pertama (hari 14, 15 dan 16). Hasil observasi terlihat bahwa subjek sering keluar masuk kelas untuk menengok ibunya atau meminta ibu untuk membenarkan bajunya sebagai alasan. Subjek masih terlihat takut ketika ditinggalkan oleh ibunya, walaupun terlihat bersemangat mengikuti program token ekonomi dan mampu mengumpulkan 5 stiker. Pada hari ke-17 sampai 28 terjadi ketidakmunculan perilaku menengok figur lekatnya. Artinya, subjek mampu mengurangi perilaku lekatnya. Walaupun pada hari ke-24, 25 dan pada akhir perlakuan hari ke-34 menunjukkan perilaku menengok figur lekatnya kembali. Hasil wawancara orangtua mengemukakan bahwa terjadi kecemasan pada subjek untuk ditinggal ibunya di sekolah dan ketakutan akan kasih 
sayangnya direbut oleh adiknya sehingga perilaku memastikan keberadaannya figur lekatnya muncul kembali. Selain itu, kondisi psikologis orangtua yang merasa kurang memberikan dorongan kepada subjek penelitian sehingga kurang adanya semangat menjalankan program token ekonomi.

Perilaku lekat II: perilaku menanyakan materi/tugas kepada ibunya dibanding gurunya. Grafik perilaku anak lebih senang menanyakan tugas pada ibunya dibanding pada gurunya menunjukkan bahwa pada fase baseline perilakunya terlihat tinggi dan setelah diberi perlakuan perilakunya cenderung menurun. Gambar 2 di bawah ini menyajikan perubahan perilaku lekat anak.

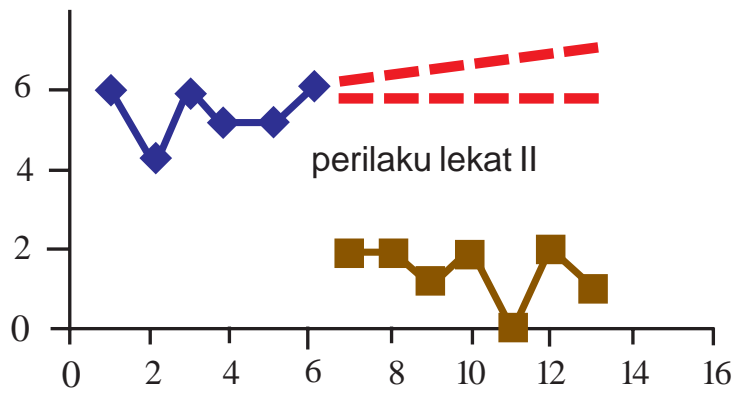

Gambar 2

Perubahan perilaku lekat II anak

Pada perilaku anak lebih sering menanyakan tugas kepada ibunya dibanding gurunya menunjukkan penurunan perilaku walaupun terjadi kemunculan kembali saat hari ke-19, 31 dan 35. Hasil wawancara dengan orangtua menyatakan bahwa pada saat perilaku lekat muncul kembali ketika terjadi konflik antara ibu dan ayahnya pada hari tersebut. Selain itu karena orangtua yang tidak mampu mengkondisikan program kepada subjek sehingga subjek terbangun kesiangan dan akibatnya merasa adanya ketakutan untuk ditinggalkan seorang diri. Data ini memperkuat dari hasil observasi bahwa subjek tampak murung dan malas untuk menulis tugas dari guru, subjek tampak menangis dan keluar masuk kelas untuk menanyakan tugasnya. Selain itu, faktor kejenuhan orangtua dalam melakukan program token ekonomi. Orangtua merasa sudah bosan dan lelah atas perubahan yang terjadi pada anaknya.

Perilaku lekat III: perilaku mendekat ibunya ketika istirahat dibanding dengan temannya. Grafik perilaku anak lebih senang mendekat kepada ibunya dibandingkan dengan temannya ketika istirahat menunjukkan penurunan yang tidak stabil pada fase perlakuan, frekuensi kemunculannya cenderung naik turun dan baru terjadi 
penurunan yang menetap pada akhir fase perlakuan. Gambar 3 di bawah ini menyajikan perubahan perilaku lekat anak.

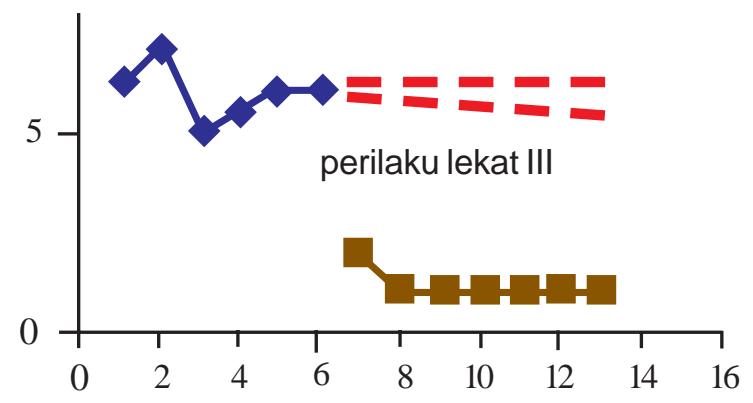

Gambar 3.

Perubahan perilaku lekat III anak

Pada awal perlakuan tampak subjek masih belum mampu untuk membaur dan terlihat masih tergantung dengan figur lekatnya ketika istirahat. Hasil observasi menyatakan bahwa subjek masih mendekat ibu ketika istirahat datang atau sebaliknya, ibu yang cenderung mendekati subjek ketika istirahat hanya untuk dapat makan atau sekedar menayakan pelajaran yang tidak dimengerti oleh. Akan tetapi diakhir perlakuan tampak bahwa anak sudah mulai bersosialisasi, terlihat mampu membeli jajan sendiri tanpa bantuan ibunya dan mampu mengatur uang jajannya.

Perilaku lekat IV: perilaku meminta ditunggu didepan kelas oleh ibunya saat sekolah. Grafik pemantauan terhadap perilaku ditunggu didepan kelas saat sekolah menunjukkan pada fase baseline (tanpa perlakuan) perilaku tersebut terjadi setiap hari. Pada fase perlakuan terjadi penurunan perilaku ditunggu didepan kelas namun terjadi kenaikan pada pertengahan perlakuan dan diakhiri dengan penurunan kembali. Pada fase perlakuan tahap pertama dan kedua, subjek telah berhasil melewati tahapan untuk ditunggu disamping pagar dan di luar pagar oleh ibunya namun saat memasuki tahap untuk dapat ditinggal dan dijenguk ibu ketika istirahat, subjek menunjukkan perilaku tidak mau ditinggal oleh ibunya sehingga muncul perilaku ditunggu kembali. Akan tetapi pada akhir perlakuan subjek mampu ditinggal oleh ibunya, dan ibunya hanya mengantar dan menjemput saat pulang sekolah. Gambar 4 di bawah ini menyajikan perubahan perilaku lekat anak.

Hasil penelitian menunjukkan penerapan token ekonomi mampu menurunkan perilaku lekat di sekolah pada anak yang mengalami gangguan kecemasan berpisah. Artinya dalam penelitian ini terdapat efek terapi, yaitu pengurangan perilaku lekat di 
sekolah pada subjek penelitian dari fase baseline (A) ke fase perlakuan (B). Menurunnya perilaku lekat pada subjek penelitian menandakan bahwa hipotesis dalam penelitian ini diterima.

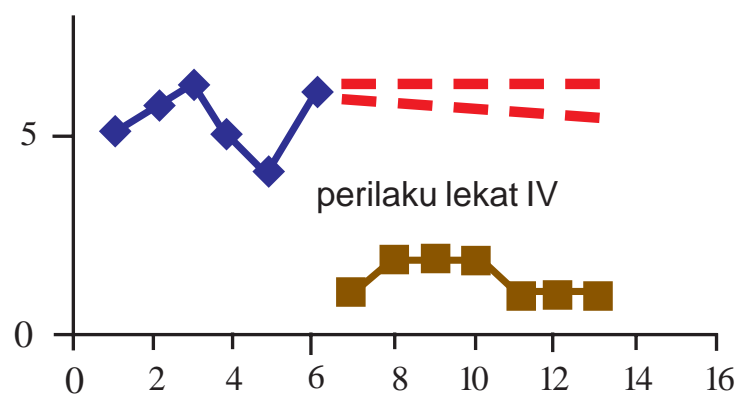

Gambar 3.

Perubahan perilaku lekat IV anak

Terjadinya penurunan secara stabil pada perilaku lekat I, perilaku lekat II dan perilaku lekat IV saat diberikan program token ekonomi, namun terjadi penurunan yang kurang stabil pada perilaku lekat III. Frekuensi kemunculannya cenderung naik turun dan baru terjadi penurunan yang menetap pada akhir fase perlakuan. Hal tersebut terjadi karena selain perilaku ibu yang menunjukkan adanya kelekatan pada subjek untuk menanyakan tugas yang dipelajarinya atau hanya sekedar mengajaknya untuk membeli jajan, subjek juga belum mampu dikondisikan untuk memegang uang jajan sendiri akibatnya subjek masih tergantung oleh ibunya saat istirahat.

Berdasarkan uraian di atas, bahwasanya hasil penelitian bukan hanya pengaruh terapi token ekonomi yang telah berjalan dalam penelitian namun adanya faktor dari luar yang mempengaruhi keberhasilan terapi, karena faktor psikologis orangtua yang terlibat. Latar belakang yang merupakan kemungkinan faktor penyebab terjadinya perilaku lekat di sekolah pada anak yang mengalami gangguan kecemasan berpisah adalah masalah orangtua. Sikap ayah yang terlalu overprotektif dan ibu yang terlalu banyak terlibat memberikan kontribusi kecemasan berpisah yang tinggi pada subjek penelitian. Connolly dkk (2006) mengemukakan bahwa pada orangtua yang overprotective, overcontrolling, atau terlalu kritis dapat mencegah anak-anak mereka dari mengembangkan kemandirian dan rasa percaya diri, dan mungkin juga meningkatkan risiko untuk kecemasan gangguan pada anak-anak mereka. Rapee (1997) menyatakan sikap overprotection orangtua secara konsisten memberikan kontribusi bagi kecemasan masa kanak-kanak. Anak-anak merasa otonominya lebih dibatasi dan menumbuhkan ketergantungan kepada orang tua (Hudson \& Rapee, 2001). 
Sedangkan sikap ibu yang terlalu banyak terlibat pada aktivitas anaknya karena khawatir tidak mampu melakukan tugas secara mandiri merupakan proyeksi kecemasan yang dinampakkan orangtua. Hasil wawancara ibu, bahwasanya ibu merasa khawatir ketika harus melepaskan subjek untuk melakukan tugasnya secara mandiri terutama di sekolah sehingga ibu harus terlibat dalam semua aktivitas anaknya. Hal senada diungkapkan oleh guru wali kelas bahwa perilaku lekat pada subjek muncul karena keterlibatan orangtua dalam mendidik anaknya. Orangtua terutama ibu cenderung ikut terlibat pada urusan anaknya sehingga anak merasa tidak terbiasa ketika harus melakukan aktivitas sendiri tanpa bantuan figur lekatnya.

Menurut Bowbly (Wood, 2007) keterlibatan orangtua dalam aktivitas anak merupakan faktor resiko berkembangnya perilaku lekat anak-orangtua sebagai hasil kecemasan yang meningkat. Begitu pula pada anak yang mengalami kecemasan berpisah senantiasa memiliki kebutuhan untuk bersama dengan figur lekatnya untuk menerima cinta dan mendapatkan dukungan atas aktivitas yang dilakukannya seperti terlibat pada aktivitas sosial.

Terjadinya kecemasan dan ketegangan emosi dalam keluarga subjek memungkinkan adanya triangulasi keluarga. Menurut Bowen (dalam Nichols dan Schwart, 1998) triangulasi dalam keluarga terjadi karena adanya kerenggangan hubungan antar keluarga; anak dengan ayah, anak dengan ibu atau ibu dengan ayah. Dalam triangulasi ini, satu pasangan akan mendekat pada salah satu pihak yaitu anak mendekat pada ibunya. Artinya, anak akan memiliki simpati kepada ibu dan berusaha menjauh dari ayah.

Ecke, Chope \& Emmelkamp (2006) juga mengemukakan bahwa kecemasan disebabkan oleh ketidakseimbangan dalam keluarga dan triangulasi merupakan salah satu cara menstranfer kecemasan dari sumber masalah ke masalah yang lain. Dalam kaitannya dengan permasalahan yang terjadi pada subjek bahwa sikap ayah yang terlalu mendominasi dan banyak menuntut dalam keluarga, sedangkan kondisi ibu yang tidak memiliki coping yang baik terhadap masalah yang dihadapi, memungkinkan bagi ibu bekerjasama dengan subjek untuk menjauhi figur ayahnya sehingga ibu pencemas secara langsung telah memproyeksikan kecemasan yang dimiliki pada anaknya yang mengakibatkan perilaku lekat. Connolly (2006) menyebutkan bahwa pada orangtua yang pencemas secara tidak sadar mendorong keterampilan coping cemas dan penghindaran pada anak-anak mereka dalam keinginan mereka untuk menjaga anak aman dari bahaya. Pendapat lain dari Perlmutter dkk (dalam Carr, 1999) mengemukakan bahwa kecemasan anak muncul ketika dalam keluarga dimana orangtua sebagai figur lekat yang berperan sebagai model bagi anaknya mempunyai 
pengaruh besar terbentuknya perilaku cemas dalam diri anak sehingga anak semakin lekat dengan ibunya dan mengalami kecemasan ketika berpisah.

Perspektif behavioral menerangkan bahwa seseorang akan mengulang aktivitasnya apabila aktivitas serupa yang dilakukan sebelumnya mendatangkan hasil yang menyenangkan, memuaskan, mendapat reward atau reinforcement yang disebut juga dengan intensif. Insentif adalah stimulus positif atau negatife yang dapat memotivasi subjek. Penguatan (reinforcement) dalam suatu kegiatan juga memberikan pengaruh pada pembentukan perilaku lekat yang terjadi pada anak. Misalnya, ketika subjek meminta ibunya untuk menunggu di depan kelas dan menangis atau mogok tidak mau sekolah jika keinginannya tidak dituruti. Artinya ketika ibu menuruti kemauan subjek maka pertahanan ibu hilang dan subjek mendapatkan penguat pada perilakunya. Pertahanan yang demikian merupakan satu bentuk stimulus yang direspon dan diulangi subjek yang digunakan sebagai bentuk pertahanan diri dalam memelihara perilaku. Perilaku meminta di tunggu di depan kelas ketika belajar akan cenderung berulang dan dipertahankan, karena subjek berfikir dengan menangis dan menarik diri untuk mogok sekolah subjek mendapat penguat, ia akan mendapatkan apa yang diinginkannya atau mencapai tujuannya.

Teknik pertama yang dilakukan adalah bagaimana mengubah pola fikir subjek yang pada awalnya berfikir untuk mendapatkan sesuatu yang diinginkan subjek menunjukkan perilaku lekat di sekolah, diubah menjadi untuk mendapatkan sesuatu yang diinginkan atau disenangi subjek harus menunjukkkan perilaku mandiri tanpa kehadiran figur lekat di sekolah, dengan cara memberikan penguat ketika subjek menunjukkan perilaku mau ditinggal dan tidak menangis tanpa ibu di sisinya. Penguat yang diberikan berupa stiker sebagai bentuk tokennya. Tujuan dari token ini adalah agar anak termotivasi mengumpulkan stiker dalam jumlah tertentu dan dapat ditukarkan dengan hadiah yang diinginkan.

Hasil penelitian terhadap subjek penelitian membuktikan bahwa penggunaan token ekonomi dapat menurunkan perilaku lekat di sekolah pada anak yang mengalami gangguan kecemasan berpisah pada orangtua. Keberhasilan penerapan token ekonomi yang telah dicapai dalam penelitian ini mendukung beberapa penelitian terdahulu yang menyatakan bahwa token ekonomi efektif untuk mengatasi masalah perilaku, diantaranya perilaku hiperaktivitas, perilaku agresif, perilaku mengganggu dan perilaku social yang tidak sesuai.

Hasil penemuan ini sejalan dengan pendapat Eisen dan Schaefer (2005) tentang penerapan terapi perilaku dengan token ekonomi cocok digunakan pada anak yang mengalami gangguan kecemasan berpisah. Alasannya hasil perilaku dapat dikontrol 
melalui konsekuensi-konsekuensi yang diberikan karena adanya target pengurangan kecemasan. Apabila hasil target tertentu mendapatkan reward, maka akan memperoleh manfaat dengan berulangnya perilaku tersebut. Jika perilaku tidak mendapat reward maka perilaku tidak akan muncul lagi. Hal ini tampak pada grafik perilaku menengok pada figur lekat untuk memastikan keberadaannya, perilaku menanyakan materi/tugas kepada figur lekatnya dibanding gurunya, perilaku memilih mendekat figur lekat ketika istirahat dibanding bermain bersama teman dan perilaku menunggu didepan kelas saat reward diberikan pada intervensi, maka frekuensi kemunculan perilaku menurun. Sebaliknya, saat reward tidak diberikan di fase baseline maka frekuensi perilaku lekat meningkat.

Uraian di atas menjelaskan tentang manfaat serta keberhasilan penerapan program token ekonomi yang telah dilaksanakan dalam penelitian ini, akan tetapi penelitian ini juga mempunyai kelemahan yang tidak bisa dipungkiri. Kelemahan dalam penelitian ini adalah; 1). Prosedur pemberian token (stiker) sebagai penguat positif yang bermacam sehingga terlalu rumit untuk dikonfersikan pada hadiah yang diinginkan 2). Keterbatasan waktu yang digunakan dalam proses peyapihan pengukuh dalam penerapan pembentukan perilaku baru, sebab dalam waktu satu minggu yang digunakan sangat sulit untuk melihat efek perubahan sebuah terapi 3). Pada proses penelitian ini perlu adanya pendampingan khusus kepada orangtua secara optimal karena orangtua yang pencemas merupakan pemicu kecemasan yang terjadi pada subjek penelitian sehingga subjek mengadaptasi kecemasannya dengan menjadikannya sebagai figur kelekatan.

\section{Simpulan}

Hasil penelitian menunjukkan penerapan token ekonomi dapat menurunkan perilaku lekat di sekolah pada anak yang mengalami gangguan kecemasan berpisah, ada perbedaan perilaku lekat di sekolah antara sebelum dan sesudah diberikan program token ekonomi pada subjek penelitian. Dari hasil observasi dan wawancara, subjek telah mampu mandiri untuk mampu diantar dan dijemput ibunya ketika sekolah tanpa harus ditunggu kembali diakhir perlakuan. Selain itu, hasil penelitian juga menemukan bahwa kondisi psikologis orangtua terutama ibu sebagai figur lekatnya sangat mempengaruhi keberhasilan suatu terapi. 


\section{Daftar Pustaka}

American Psychiatric Association (2000). Diagnostic and Statistical Manual of Mental Disorders. Text revision (4th edition). Washington DC.

Barlow, D.H. \& Hersen, M., \& Pergamon, W. (1984). Single case experimental designs: strategies for studying behavior change. ( $2^{\text {nd }}$ Ed) General Psychology Series. New Yowk USA: Pergamon Press.

Carr. A. (2001). Abnormal psychology. New York: Francis: Psychology Press Taylor $\&$ Francis Group.

Chorpita, B. F. (2001). Control and the development of negative emotion. In M. W. Vasey \& M. R. Dadds (Eds.), The developmental psychopathology of anxiety. New York: Oxford University Press.

Corey, G. (1997). Teori dan praktek konseling dan psikoterapi. Penerjemah: Koeswara. Bandung: Refika Adifama.

Connolly, S., Cynthia, L.P., \& David, A.S. (2006). Anxiety disorders. New York: Chelsea House An imprint of Infobase Publishing.

Dagun, M. (2002). Psikologi keluarga (peranan ayah dalam keluarga). Jakarta: Rineka Cipta.

Doobay, F. (2008). School refusal associated with separation anxiety disorder: a cognitive-behavioral approach to treatment. Journal of Psychology in the school, 45(4), 132-144.

Durkin, K., (1995), Developmental social psychology. Massachussets: Blackwell Publisher Inc.

Ecke, V.Y., Chope, C.R., \& Emmelkamp, M.P. (2006). Bowbly and Bowen: Attachment theory and family therapy. Counseling and clinical psychology journal. Volume: 3 (2). Retrieved from www.psychologicalpublishing.com.

Eisen, R.A., \& Schaefer E.C. (2005). Separation anxiety in children and adolescents an individualized aprroach to assessment and treatment. New York: The Guilford Press.

Field, C.E., Nash, H. M., Handwerl, M. L., \& Firman, P.C. (2004). A modification of the token economy for nonresponsive youth in family-style residential care. Behavior Modification, 28, 438-457. 
Flood, W.A., \& Wilder, D.A. (2004). The use of defferential reinforcement and fading to increase time away from a caregiver in a child with separation anxiety disorder. Journal of Education \& Treatment of Children, Vol. 27. No 1.

Gosschalk, P.O. (2004). Behavioral treatment of acute onset school refusal in a 5year old girl with separation anxiety disorder. Journal of Education \& Treatment of Children, 150(11), 223-234.

Higim, J.W, William R.L, \& McLauglin T.F. (2001). The effects of a token economy employing instructional consequenses for a third-grade student with learning disability. Journal of Education and Treatment of Children. 24(1), 432-447.

Hudson, J. L., \& Rapee, R. M. (2001). Parent-child interactions and anxiety disorders: An observational study. Behavior Research and Therapy, 3(3), 143158.

Kearney, A.C. (2001). School refusal behavior a function approach to assesment and treatment. Washington, DC: Prentice Hall, Inc.

Kearney, A.C., Sims, E.K., Pursel, R.C., Tillotson, A.C. (2003). Separation anxiety disorder in young children: A longitudinal and family analysis. Journal of Clinical Child and Adolescent Psychology, 32 (4), 593-598.

Le Fanu, J. (2006). Deteksi dini masalah-masalah psikologi anak. Yogyakarta: Think.

McLaughlin, T.F., \& Williams, R. L. (1998). The Token Economy In J.C. Witt, S.N. Elliot \& F.M. Gresham (eds), Handbook of Behavior Therapy in Education. New York: Pleum.

Mofrad, S., \& Herbert, M. (2009). Maternal psychological distress and separation anxiety disorder in children. European Journal of Social Sciences, 8(3), 223-237.

Mofrad, S., \& O'Reily, N. (2010). Attachment patterns and separation anxiety symptom. Journal Asian Social Science, 6(11), 323-340.

Monks, P.J., Knoers, A.M.P., \& Harditono, S.R. (2002). Psikologi perkembangan: Pengantar dalam berbagai bagiannya. Yogyakarta: Gajah Mada University Press.

Nichols, B., \& Schwartz, P. (1998). Family therapy concepts and methods. (Fourth edition). USA: Allyn and Bacon. 
Ningsih, I. G. (2008). Token ekonomi untuk menurunkan perilaku agresif pada anak usia prasekolah. Tesis (tidak diterbitkan). Yogyakarta: Universitas Gadjah Mada.

Obegi, H.J., \& Berant, E. (2009). Attachment theory and research in clinical work with adults. New York: The Guilford Press.

Rapee, R. M. (1997). Potential role of childrearing practices in the development of anxiety and depression. Clinical Psychology Review, 8(3), 243-255.

Suprihatin, T. (2009). Token ekonomi untuk meningkatkan perilaku memperhatikan pada siswa sd yang mengalami gejala gangguan pemusatan perhatian dan hiperaktivitas (GPPH). Tesis (tidak diterbitkan). Yogyakarta: Program Magister Profesi Psikologi UGM.

Swoboda, C.M., Kratochwill, T.R., \& Levin, J.R. (2010). Conservative dualcriterion method for single-case research: A guide for visual analysis of $A B, A B A B$, and multiple-baseline designs (WCER Working Paper no. 2010-13). Retrieved from University of Wisconsin-Madison, Wisconsin center for Education Research website:http://www.wcer.wisc.edu/ publications/workingPapers/papers.php

Wood, J.J. (2007). Dependency on elementary school caregivers: the role of parental intrusiveness and children's separation anxiety. Journal of Psychology in the schools, Vol 44 (8). Published online in Wiley InterScience (www.interscience.wiley.com ).

Zlomke, K. (2003). Token economy plus self-monitoring to reduce distructive classroom behavior. The Behavior Analyst Today, 4(2), 23-37. 